\title{
The effect of customer relationship management on customer satisfaction and competitive advantage
}

\author{
Hasan Dehghan denavi \\ Associate Professor, Department of Industrial Management, Yazd Branch, \\ Islamic Azad University, Yazd, Iran \\ Seyed Hamid Emadi * \\ Ph.D. Student, Department of Industrial Management, Yazd Branch, \\ Islamic Azad University, Yazd, Iran \\ Mehrdad shahbazi manshadi \\ Ph.D. Student, Department of Industrial Management, Yazd Branch, \\ Islamic Azad University, Yazd, Iran \\ *Corresponding Author: Hamid.emadi7@gmail.com
}

\begin{abstract}
This research has been conducted with the aim of investigating the impact of customer relationship management on customer satisfaction and competitive advantage in two service companies. Therefore, the variables of customer relationship management, customer satisfaction and competitive advantage have been defined according to the research topic. This is an applied research regarding objective and it is descriptive-correlation in term of nature and method. It includes 95 people as statistical population and 76 people as statistical sample. At first, research's reliability and validity have been studied. Research's hypotheses have been tested using structural equation modeling techniques with partial least squares approach. The obtained results indicate confirmation of all the hypotheses.
\end{abstract}

Keywords: Customer relationship management, Customer satisfaction, Competitive advantage.

\section{Introduction}

With the markets globalization expansion, the only way which continues the survival of companies and organizations is competitiveness increase and sustainable competitive advantage achievement and maintenance. Serving the customers must be the focus of activities in order to achieve competitiveness. Today, the competition between individual companies has been replaced with competition between supply chains. Supply chains connect suppliers to a manufacturing company and the company to its customers. We should be sure of customer service, low cost, and short cycle times in order to properly manage the supply chain, (Louden, 2011). Therefore, the nature of the competitive environment in which the organization operates convert the concern for competitive advantage into a critical issue (Casinos, 2005; Porter and Cramer, 2006; Liao and Hu, 2007). Providing an accurate definition of competitive advantage is a difficult task (Hakkak \& Qodsi, 2015). But in term of a competitive strategy and creating value, competitive advantage is everything that increases revenue more than cost (Rommel, 2003). It can be also said that competitive advantage is ability to construct products and provide service that are more valuable for customers compared with other competitors' products and services (Garrett et al., 2001) which somehow cause organization to have a defensive stand against other rivals (Barney, 1991). In addition, competitive advantage exists because the customer understands a distinct difference in the important characteristics of the products or services of the manufacturer and its competitors (Agah et al, 2012). On the other hand, in today's highly competitive market, companies should have a positive relationship with their customers because a good customer relationship management leads to satisfaction for customers and fulfills their needs (Hassan et al, 2015) and this will lead to customers relationship improvement and finally increase their loyalty and maintenance and it will also cause a better competitive advantage compared with others (Nejayi, 2005, Brawn et al, 2014 \& Sayani, 2015).

Therefore, given the importance of customer satisfaction and gaining competitive advantage in today's competitive world, this study examines the effect of customer relationship management on customer satisfaction and competitive advantage. 


\section{An overview of the research background}

Some studies have been conducted in term of customers in the field of customer relationship management, competitive advantage and customer satisfaction and relationship between customer relationship management, competitive advantage and customer satisfaction that we refer to some of them. Moya Adelke et al (2018) conducted a research entitled "themethods of strategic customer relationship management, employee perceptions and its effect on competitive advantage and organizational performance in Nigerian banking sector. Data were collected using 240 questionnaires distributed to employees and 200 number of which were answered. Then, they were analyzed by SPSS and linear regression and the hypotheses were investigated. The results of this research showed that customer relationship management has an important impact on competitive advantage.

Bat et al. (2016) conducted a research entitled "customer relationship management: An Approach to competitive advantage in the banking sector by investigating the mediator role of loyalty". . In this research, the research model has been designed and developed following an exact literature review. This model consists of four predictor variables including complaint clarity, customer orientation, customer empowerment and customer knowledge which influence the outcome variables such as customer loyalty and competitive advantage. A structural equation model has been used and the results have been analyzed in order to test the various causal relationships between variables in the model. This research aims to develop a CRM model based on a customercentered perspective which can be used by the service industry in the public and banking industries. According to the results, it can be concluded that customer knowledge has a significant impact on customer loyalty. Loyalty can be increased by directly understanding the customer's dynamic behavior and maintaining customer information directly from the bank. Addressing customer complaints and providing the appropriate resolution for them can convert a potential customer into a loyal customer. In addition, managerial skills, knowledge management, customer orientation and customer empowerment can be added. . Finally, customer relationship management is a powerful factor to influence competitive advantage.

Hassan et al (2015) conducted a research entitled "the impact of customer relationship management and customer satisfaction". This is a preliminary study based on data. The information was collected through a questionnaire distributed among 100 employees of Al-Falah Bank, Muslim Islamic Bank, Meezan Bank, Allied Bank, and other banks in Islamabad. Regression analysis has been used to analyze the data. The results of this study indicate that customer relationship management has a significant impact on customer satisfaction. Matthews et al. (2005) conducted a research entitled "why customer relationship management programs affect customer satisfaction?" This research studies the effect of customer relationship management (CRM) on customer knowledge and customer satisfaction. Analyzing archive data using the least squares method for a section of US firms shows that the use of CRM applications has been positively improved with customer knowledge and customer satisfaction. This article also shows that if the company shares customer information with its supply chain partners, customer information will be enhanced.

\section{Research's conceptual model and hypotheses}

According to past research, we will define the main variables of the research in this section including customer relationship management, competitive advantage, and customer satisfaction. Customer relationship management (CRM) is increasingly recognized as a tool for developing innovative capabilities and providing a long-term competitive advantage (Lin et al., 2010). Customer relationship management enables a company to better understand its customers through obtaining customer's information. This is an important factor in customer's goals determination and maintaining them, operations optimization and forecasting demand. Customer relationship management as a philosophy considers customer loyalty as a key to the success of business profitability and long-term competition (Seddiqi et al., 2011). Companies should change their focus from losing new customers to maintaining their own customers in order to achieve loyalty (Rich Hold, 2006). This philosophy leads organizations to create a customer-centered culture with an emphasis on customer needs (Pilkey et al., 2003). ) According to Wright et al. (2006), some companies ignore customer capability as customer-centered dimensions of customer relationship management, but many companies try to improve customer satisfaction, loyalty and empowerment. Therefore, marketing must be properly regulated and prepare itself for decision making to improve the quality of service provision through reviewing consumer expectations and the current condition of customer relationship management. Therefore, the purpose and effect of such an orientation toward the customer is increasing the customer satisfaction and creating loyalty and trust in the customer. It is therefore argued that customer empowerment significantly affects the long-term competitive advantage and results in better business results (Javdena \& Foley, 2000). 
In terms of customer satisfaction, we can say that all definitions of customer satisfaction have one thing in common and this is the fact that, the customer will makes an assessment of the goods and services after making a purchase that this assessment leads to satisfaction. The overall satisfaction of the customer is the consequent of all the relationships that a firm has during the transaction with each customer. Not only the good, but also the offered services are also assessed. Customer satisfaction is customer's general attitude towards the service provider or an emotional reaction to the difference between expectations and perceptions given the satisfaction of some needs, goals or desirability (Mark Hausen, 2004). Concerning the competitive advantage, Porter (2004) states that competitive advantage is primarily a value that a company can create for its buyers and this is nothing more than the cost of the company. On the other hand, the pure concept of performance advances pursue some operational which according to Murgeson et al. (2012) means competitive advantages such as quality, costs, price, delivery speed, delivery compliance, innovation, and flexibility (as example better, cheaper, faster and faster). According to the above mentioned principles, the following hypotheses have been considered and tested:

The main hypothesis: customer relationship management affects customer satisfaction and competitive advantage.

Sub-hypotheses: Customer relationship management affects customer satisfaction.

Customer relationship management affects competitive advantage.

The conducted studies indicate that a research that simultaneously examines the impact of customer relationship management on customer satisfaction and competitive advantage was not observed.

Therefore, with the above mentioned content, the proposed model of the research is presented as follows:

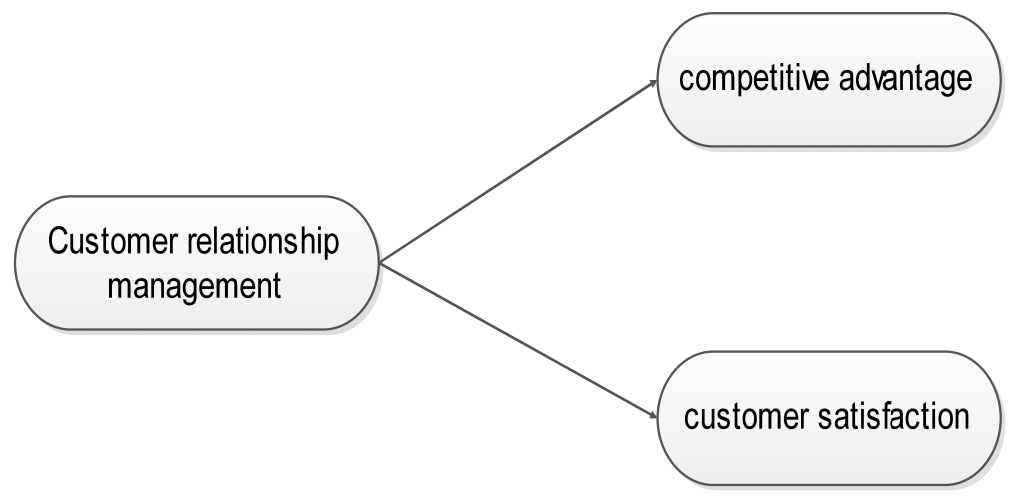

Figure 1- Research's conceptual model

\section{Research method}

This is an applied research in term of objective and a descriptive-correlation one regarding nature and research method. This research includes 95 people as statistical population and 76 people as statistical sample. Information has been collected through Kornaiti's customer relationship management and customer satisfaction questionnaire (2015) and competitive advantage questionnaire of Lee et al (2006). In this study, the construct convergent validity technique was used to test validity of the questionnaires used in the research and the composite reliability and Cronbach's alpha techniques were used in order to determine reliability. Constructconvergent validity has been evaluated using confirmatory factor analysis (LISREL Software). Also, research hypotheses are tested using structural equation modeling technique with partial least squares approach and the fittest of the measurement model, structural model and general model should be investigated before examining the research hypotheses. Two criteria must be considered in order to evaluate construct-convergent validity: 1 . the factor load for each variable must be greater than 0.5 and it should be ideally greater than 0.7. 2- The average of the extracted variance for each variable must be greater than 0.5 (Ramin Mehr, and Cherastad, 2013). Also, composite reliability and Cronbach's alpha have been calculated using LISEREL and SPSS software. Table 1 shows the validity and reliability of the questionnaires used in the research. 
Table 1 : Factor loadings, Cronbach's $\alpha, \mathrm{CR}$ and AVE of questionnaires

\begin{tabular}{|c|c|c|c|c|c|c|c|}
\hline \multicolumn{2}{|l|}{ criteria } & Items & Factor & $t>1.96$ & AVE & CR & Cronbach's \\
\hline \multirow{4}{*}{\multicolumn{2}{|c|}{ CRM }} & $\begin{array}{l}\text { communication }- \text { information: } \\
\text { giving the right information to } \\
\text { customers based on organizational } \\
\text { principles }\end{array}$ & 0.91 & $\checkmark$ & \multirow{4}{*}{0.767} & \multirow{4}{*}{0.929} & \multirow{4}{*}{0.909} \\
\hline & & $\begin{array}{l}\text { communication }- \text { relationship: } \\
\text { building good relationship with } \\
\text { customers }\end{array}$ & 0.86 & $\checkmark$ & & & \\
\hline & & $\begin{array}{ll}\text { trust: providing guarantee } & \text { to } \\
\text { customers over fund they keep } & \\
\end{array}$ & 0.90 & $\checkmark$ & & & \\
\hline & & $\begin{array}{l}\text { commitment: committed to } \\
\text { customers, ensuring customers that } \\
\text { profit sharing does not violate the }\end{array}$ & 0.83 & & & & \\
\hline \multirow{6}{*}{\multicolumn{2}{|c|}{$\begin{array}{l}\text { Customer } \\
\text { Satisfaction }\end{array}$}} & $\begin{array}{l}\text { customers are actively doing } \\
\text { transactions }\end{array}$ & 0.82 & $\checkmark$ & \multirow{6}{*}{0.671} & \multirow{6}{*}{0.924} & \multirow{6}{*}{0.894} \\
\hline & & $\begin{array}{l}\text { customers support or recommend } \\
\text { products or showing loyalty }\end{array}$ & 0.85 & $\checkmark$ & & & \\
\hline & & $\begin{array}{l}\text { customers keep supporting or } \\
\text { showing loyalty or adopting }\end{array}$ & 0.76 & $\checkmark$ & & & \\
\hline & & $\begin{array}{l}\text { customers are more loyal (keep } \\
\text { using the products or services } \\
\text { offered despite emerging }\end{array}$ & 0.78 & $\checkmark$ & & & \\
\hline & & $\begin{array}{l}\text { satisfaction over the products or } \\
\text { service offered by sharia banks }\end{array}$ & 0.82 & $\checkmark$ & & & \\
\hline & & overall satisfaction on sharia banks & 0.88 & $\checkmark$ & & & \\
\hline \multirow[b]{2}{*}{ Price/cost: } & \multirow{14}{*}{ 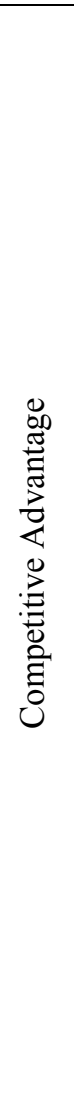 } & We offer competitive prices. & 0.85 & $\checkmark$ & \multirow[b]{2}{*}{0.757} & \multirow[b]{2}{*}{0.862} & \multirow[b]{2}{*}{0.855} \\
\hline & & $\begin{array}{l}\text { We are able to offer prices as low } \\
\text { orlower than our competitors. }\end{array}$ & 0.89 & $\checkmark$ & & & \\
\hline \multirow{3}{*}{ Quality } & & $\begin{array}{l}\text { We offer products that are highly } \\
\text { reliable. }\end{array}$ & 0.79 & $\checkmark$ & \multirow{3}{*}{0.651} & \multirow{3}{*}{0.848} & \multirow{3}{*}{0.833} \\
\hline & & $\begin{array}{l}\text { We offer products that are very } \\
\text { durable. }\end{array}$ & 0.81 & $\checkmark$ & & & \\
\hline & & $\begin{array}{l}\text { We offer high quality products to } \\
\text { our }\end{array}$ & 0.82 & $\checkmark$ & & & \\
\hline \multirow{3}{*}{$\begin{array}{c}\text { Delivery } \\
\text { dependability: }\end{array}$} & & $\begin{array}{l}\text { We deliver the kind of products } \\
\text { needed. }\end{array}$ & 0.75 & $\checkmark$ & \multirow{3}{*}{0.722} & \multirow{3}{*}{0.886} & \multirow{3}{*}{0.874} \\
\hline & & We deliver customer order on time. & 0.92 & $\checkmark$ & & & \\
\hline & & We provide dependable delivery. & 0.87 & $\checkmark$ & & & \\
\hline \multirow{3}{*}{$\begin{array}{l}\text { Product } \\
\text { innovation: }\end{array}$} & & We provide customized products. & 0.84 & $\checkmark$ & \multirow{3}{*}{0.684} & \multirow{3}{*}{0.866} & \multirow{3}{*}{0.842} \\
\hline & & $\begin{array}{l}\text { We alter our product offerings to } \\
\text { meet client needs. }\end{array}$ & 0.84 & $\checkmark$ & & & \\
\hline & & $\begin{array}{l}\text { We respond well to customer } \\
\text { demand for "new" features. }\end{array}$ & 0.80 & $\checkmark$ & & & \\
\hline \multirow{3}{*}{$\begin{array}{l}\text { Time to } \\
\text { market: }\end{array}$} & & $\begin{array}{l}\text { We deliver product to market } \\
\text { quickly. }\end{array}$ & 0.78 & $\checkmark$ & \multirow{3}{*}{0.762} & \multirow{3}{*}{0.905} & \multirow{3}{*}{0.879} \\
\hline & & $\begin{array}{l}\text { We are first in the market in } \\
\text { introducing }\end{array}$ & 0.88 & $\checkmark$ & & & \\
\hline & & $\begin{array}{l}\text { We have time-to-market lower than } \\
\text { industry average. }\end{array}$ & 0.95 & $\checkmark$ & & & \\
\hline
\end{tabular}


According to table 1, the questions' factor load and constructs' dimensions of research's model can be observed. As it is observed in table, these entire factor loads are meaningful. Because the factor loads are greater than 0.5 (which are significant) and the average of the extracted variances are greater than 0.5 , the existence of convergent validity for each of the indexes and the main construct is confirmed. Also, all coefficients of Cronbach's alpha and composite reliability are greater than 0.7 which indicates the good reliability of the questionnaires used in the research.

\section{Findings}

In this study, the research's hypotheses are tested using structural equation modeling technique with partial least squares approach. The fittest of the measurement model, structural model and general model should be examined before examining the research hypothesis. Table 2 shows the indicators of the measurement model, structural model and the general model of the main hypothesis and sub-hypotheses of the research.

Table 2- Model's fitness indexes

\begin{tabular}{|l|l|l|l|}
\hline Fitness indexes of measurement model & CR & AVE & Index's factor load \\
\hline construct & $* 0.852$ & $* 0.596$ & Between $* 0.600$ to $* 0.893$ \\
\hline CRM & $* 0.953$ & $* 0.743$ & Between $* 0.788$ to $* 0.899$ \\
\hline Competitive advantage & $* 0.843$ & $* 0.473$ & Between $* 0.624$ to 0.757 \\
\hline Customer satisfaction & Fitness indexes of structural model \\
\hline Construct & $* 0.684$ & $* 0.681$ & 0.470 \\
\hline Competitive advantage & $* 0.505$ & $* 0.499$ & 0.182 \\
\hline Customer satisfaction & $\overline{R^{2}}$ & \\
\hline Fitness indexes of general model & \multicolumn{3}{|l|}{} \\
\hline GOF & 0.595 & 0.604 \\
\hline 0.462 & Communaltties \\
\hline$:$ significance at 0.95 confidence level & $\mathrm{Q}^{2}$ \\
\hline
\end{tabular}

The fitness of research model is investigated by evaluating factor loads and extracted mean variance, composite reliability and diagnostic validity. As it is shown in table 2, all factor loads of all questions and indexes of the main research variables are significant at $95 \%$ confidence level and there is no need to remove none of them.

The average values of extracted variance and combined reliability of research's variables are also significant at $95 \%$ confidence level.

The fitness of the structural model is also carried out by the means of indicators adjusted R2, R2 and Q2. As is observed in table 1, all the values of adjusted R2and R2 are significant. Chine (1998) introduces three values of $0.19,0.33$ and 0.67 as the criterion value for weak, moderate and strong R2 values. Accordingly, the R2 value of competitive advantage and customer satisfaction is 0.684 and 0.505 which are respectively at strong and relatively strong level. Q2 index also determines the prediction power of model. The values of $0.02,0.15$ and 0.35 respectively indicate the model's weak, moderate and strong prediction power regarding endogenous structure. The GOF criterion is used to examine the fitness of general model that controls both the measurement and structural model sections:

$\mathrm{GOF}=\sqrt{\overline{\text { Communalities }} \times \overline{\mathrm{R}^{2}}}$

Communalities: Is obtained from the average of the shared values of the indexes or research questions. Watzles et al. (2009, p.187) introduce three values of $0.01,0.25$ and 0.36 as the criterion value for weak, moderate and strong GOF values.Thus, the GOF's value which is equal to 0.4462 indicates model's strong overall fitness. Subsequently, the research hypotheses have been tested. Figure 2 shows the values of path coefficients (direct effect) of independent variables on dependent ones. In this figure, the values of $p$ are also visible: 


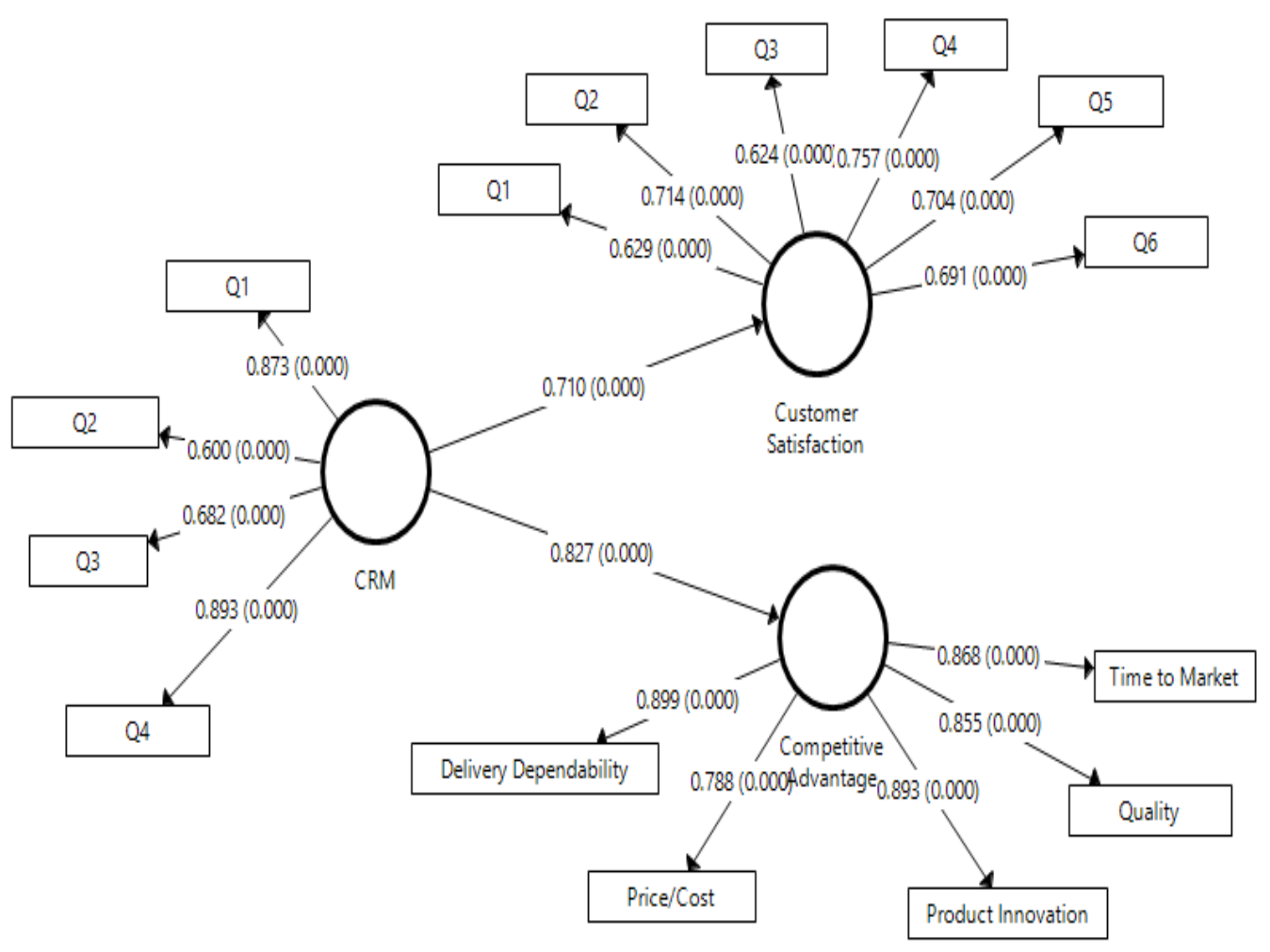

Figure 2- research's hypotheses model and statistic $p$

Figure 3 shows the path coefficients values and statistic $t$ :

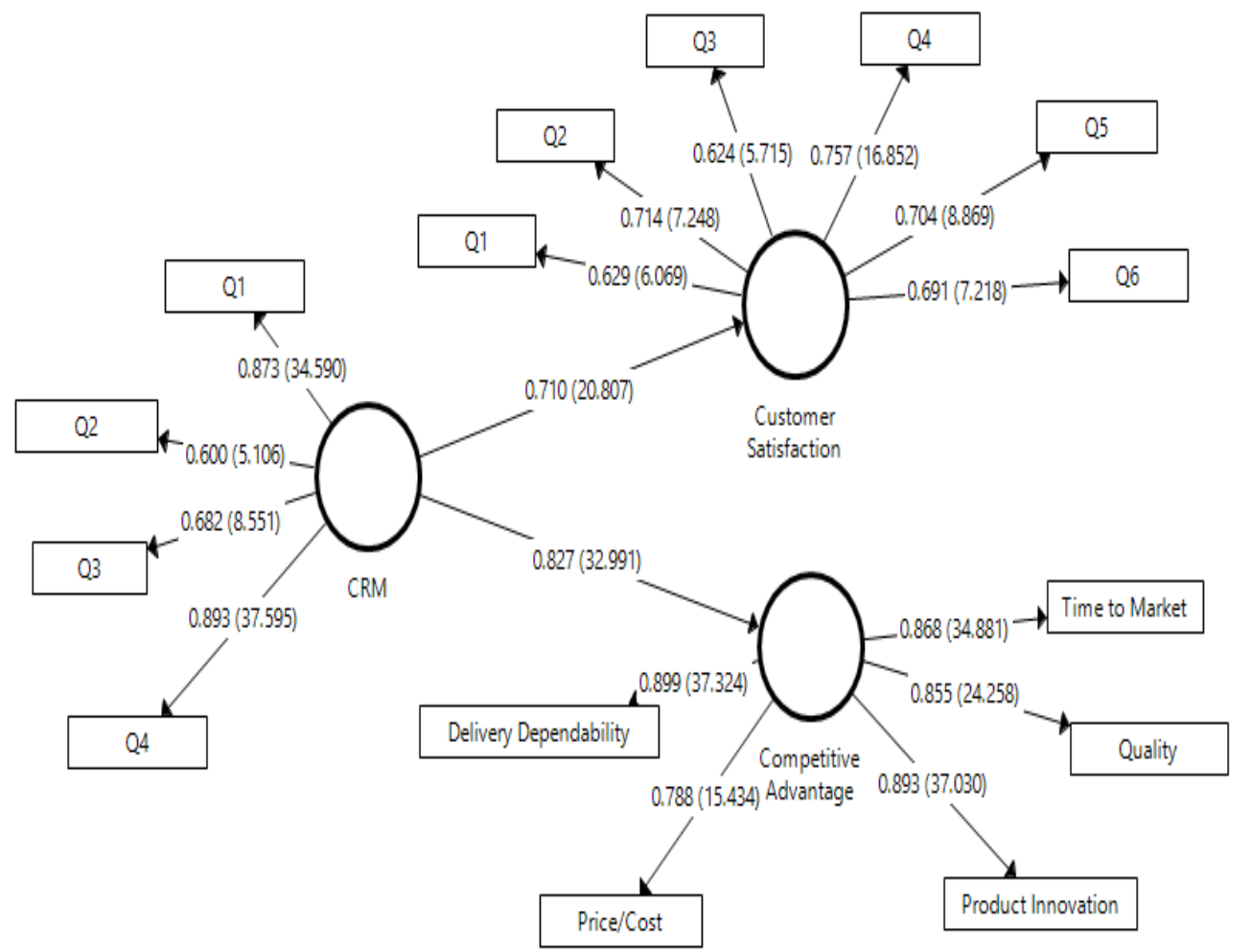

Figure 3- Research's hypotheses model and statistic t 
As it is observed in table 3, both hypotheses have been confirmed:

1. The result of the first hypothesis test showed that the impact of CRM on the competitive advantage is 0.87 . The values of $P$ and $t$ are respectively less than 0.05 and greater than 1.96 . According to the values of $P$ (less than0.05) and $t$ (greater than1.96), with 95 percent of confidence, we can be say that the research's first hypothesis is confirmed and this means that CRM has a positive and significant effect on the competitive advantage.

2. The result of the second hypothesis test showed that the impact of CRM on the customer satisfaction is 0.710. The values of $P$ and $t$ are respectively less than 0.05 and greater than 1.96. According to the values of $P$ (less than0.05) and $t$ (greater than1.96), with 95 percent of confidence, we can be say that the research's first hypothesis is confirmed and this means that CRM has a positive and significant effect on the customer satisfaction.

The table 3- shows the results of research's hypotheses test

\begin{tabular}{|c|c|c|c|c|c|c|}
\hline $\begin{array}{c}\text { Hypotheses } \\
\text { test }\end{array}$ & P value & $\mathrm{t}$ value & $\begin{array}{c}\text { Path } \\
\text { coefficient }\end{array}$ & $\begin{array}{c}\text { dependent } \\
\text { variable }\end{array}$ & $\begin{array}{c}\text { Independent } \\
\text { variable }\end{array}$ & Hypotheses \\
\hline supported & 0.000 & 32.99 & 0.827 & $\begin{array}{c}\text { Competitive } \\
\text { Advantage }\end{array}$ & CRM & 1 \\
\hline supported & 0.001 & 20.81 & 0.710 & $\begin{array}{c}\text { Customer } \\
\text { Satisfaction }\end{array}$ & CRM & 2 \\
\hline
\end{tabular}

\section{Conclusion}

The results of the research indicates confirmation of the impact of customer relationship management on competitive advantage that is consistent with the results of the research by Moya Adeca et al. (2018) and Bot et al. (2016) and it is consistent with the research of Hassan et al (2015) and Mathias et al (2005) regarding the effect of customer relationship management on customer satisfaction. In the conducted studies, there was no research that simultaneously examined the impact of customer relationship management on the competitive advantage and customer satisfaction.

\section{References}

[1] Agha, S., Alrubaiee, L., \&Jamhour, M. (2012). Effect of core competence on competitive advantage and organizational performance. International Journal of Business and Management, 7(1), 192-204.

[2] Barney, J. (1991). Firms resources and sustained competitive advantage. Journal of Management, 17(1), 791- 400.

[3] Brun, I., Rajaobelina, L. and Ricard, L. (2014), “Online relationship quality: scale development and initial testing”,International Journal of Bank Marketing, Vol. 32, No. 1, pp. 5-27.

[4] Chin, W. W. (1998). The partial least squares approach to structural equation modeling. In G. A. Marcoulides (Ed.), Modern methods for business research (pp. 295 -336). Mahwah, New Jersey: Lawrence Erlbaum Associates.

[5] Cousins, P.D. (2005). The alignment of appropriate firm and supply strategies for competitive advantage. International Journal of Operations \& Production Management, 25(5), 403-428.

[6] Garth, S., Shepard, A., \&Podolny, J. (2001). Strategic management. New York: John Wiley \& Sons.

[7] Hakkak, M., \&Ghodsi, M. (2015). Development of a sustainable competitive advantage model based on balanced scorecard. International Journal of Asian Social Science, 5(5), 298-308.

[8] Hasenmark, O. a. (2004). Customer Satisfaction and Retention: The Experiences of Individual Employees. Managing Service Quality, 14(1), 40-57.

[9] Hassan, R. S., Nawaz, A., Lashari, M. N., \& Zafar, F. (2015). Effect of customer relationship management on customer satisfaction. Procedia Economics and Finance, 23, 563-567.

[10] Jayawardhena, C. and Foley, P. (2000), "Changes in the banking sector- the case of internet banking in the UK",Internet Research, Vol. 10 No. 1, pp. 19-31.

[11] Kurniati, R. R., Suharyono, H. D., \& Arifin, Z. (2015). The effect of customer relationship marketing (CRM) and service quality to corporate image, value, customer satisfaction, and customer loyalty. European Journal of Business and Management, 7(11), 107-120.

[12] Laouden, E., (2011). Supply Chain Management: a physical programming approach. Int. J. Production Economics, In Press, Corrected Proof, Available online 22 July 2004.

[13] Li, S., Ragu-Nathan, B., Ragu-Nathan, T. S., \& Rao, S. S. (2006). The impact of supply chain management practices on competitive advantage and organizational performance. Omega, 34(2), 107-124.

[14] Liao, S.H., \& Hu, T.C. (2007). Knowledge transfer and competitive advantage on environmental uncertainty: An empirical study of the Taiwan semiconductor industry. Technovation, 27(6), 402-411.

[15] Lin, R.J., Chen, R.-H. and Chiu, K.K.-S. (2010), "Customer relationship management and innovation capability: An empirical study", Industrial Management \& Data Systems, Vol. 110 No. 1, pp. 111-133.

[16] Mithas, S., Krishnan, M. S., \& Fornell, C. (2005). Why do customer relationship management applications affect customer satisfaction? Journal of Marketing, 69(4), 201-209.

[17] Murugesan T, Kumar B, Kumar M (2012) Competitive advantage of world class manufacturing system (WCMS) — a study of manufacturing companies in south India. European Journal of Social Sciences 29(2):285-311.

[18] MuyiwaAdeleke, O., Uchenna, E. B., \& Sunday, A. O. (2018). Strategic Customer Relationship Management Practices: Employees' Perception of its Influence on Competitive Advantage and Organizational Performance in the Nigerian Banking Sector. International Journal of Innovative Research and Development, 7(2).

[19] Ngai, E.W.T. (2005), "Customer Relationship Management Research (1992-2002)”, Marketing Intelligence and Planning, Vol. 23 No. 6, pp. 582-605. 
[20] Piccoli, G., O'Connor, P., Capaccioli, C. and Alvarez, R. (2003), "Customer relationship management- A driver for change in the structure of the U.S. lodging industry, Cornell Hotel and Restaurant Administration Quarterly, Vol. 44 No. 4, pp. 61-73.

[21] Porter, M.E,, (2004) Building the microeconomic foundations of prosperity: findings from the business competitiveness index ${ }^{6}$, In Sala-i-Martin, X. (ed.), The Global Competitiveness Report 2003-2004. Oxford University Press: New York.

[22] Porter, M.E., \& Kramer, M.R. (2006). Strategy and society: The link between competitive advantage and corporate social responsibility. Harvard Business Review, 84(12), 78-92.

[23] Ramin Mehr H, Cherastad P, (2013), quantitative research method by structural equation modeling application (LIZREL software), Tehran, Termeh.

[24] Reichheld, F.F. (2006), "The ultimate question for unlocking the door to good profits and true growth", HarvardBusiness School Publishing Corporation Boston: Massachusetts.

[25] Rumelt R.P. (2003). What in the world is competitive advantage. Policy Working Paper, 105(3), 1-5.

[26] Sayani, H. (2015), "Customer satisfaction and loyalty in the United Arab Emirates banking industry",International Journal of Bank Marketing, Vol. 33 No. 3, pp. 351 - 375.

[27] Siddiqi, K.O. (2011), "Interrelations between Service Quality Attributes, Customer Satisfaction and Customer Loyalty in the Retail Banking Sector in Bangladesh", International Journal of Business and Management,Vol. 6 No. 3, pp. 12-36.

[28] Wetzels, M., Odekerken-Schroder, G., \& van Oppen, C. (2009). Using PLS Path Mode ling for Assessing Hierarchical Construct Models:Guidelines and Empirical Illustration. MIS Quarterly 33,1, 177-195.

[29] Wright, L.T. (2006), “Consumer empowerment special issue”, European Journal of Marketing, Vol. 40 No. 9/10, pp. 925-935. 